
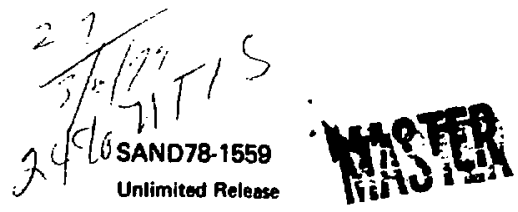

\title{
MASTER
}

\section{A Televison Assessment and Identification System for the Plutonium Protection System}

Donald A. Greenwoll

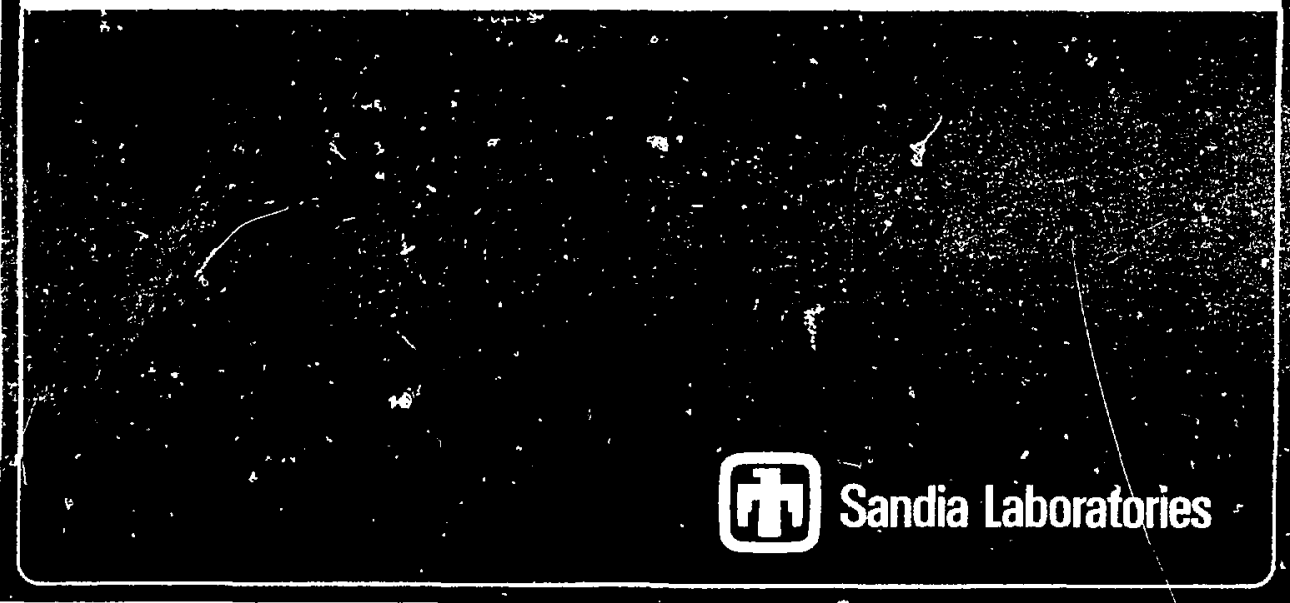

SF 200000177.31 
SANT)78- 1559

Linlimited ftelease

Printed February 1979

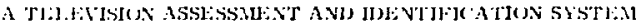

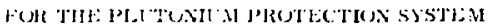

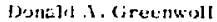

Facilit? Swstems lingineering Jivision 1 îj5

Sandia laburatorjes:

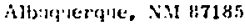

\begin{abstract}
МЗร"НАС"
This report covers the seluction, description, and use of the componerts comprising the Television Asesssment and Identification System in the Hanford Plutonium F'rotection System.

This work was sponsored by the Department of Energy/Office of Safeguards and Security (DOE/ USS) as part of the overall Sandia Fixed Facility Physical Protection Program.
\end{abstract}




\section{CONTENTS}

$\begin{array}{lr}\text { Introduction } & \text { Page } \\ \text { Summary } & 7 \\ \text { Component Description } & 9 \\ \text { Asseasment Cameras } & 10 \\ \text { Identitication Camaras } & 10 \\ \text { Cables } & 11 \\ \text { Camera Control Units } & 11 \\ \text { Video Clampers } & 11 \\ \text { Remote Video Switcher } & 12 \\ \text { Video Monitors } & 12 \\ \text { Diagnostic Equipment } & 13 \\ \text { Referenceg } & 13\end{array}$

\section{ILLUSTRATIONS}

\section{Figure}

1 Plutonium Protection Sygtem Organization

2 Physical Layout of Camerag

9

3 Block Dingram of TV System 


\section{A TELEVISION ASSE:SSMENT AND IDENTIFICATION SYSTEM FOR THE: PLUTONIUM PROTECTION SYSTEM}

\section{Introduction}

The Plutonium Prolection System (PPS) is an 1tem protection system that demonstrates advanced storage concepts which integrate detection and delay elements with careful monitoring and contral of operational procedures. In addition, the accountability. operations, and security centery are physically separated to reduce vulnerability to insider threat. Organization of the PPS is illustrated in Figure 1. The tive components of the PPS which are interconnected with a data communicatlons network:

- The Storage Vault is an Item Control Area (ICA) in which advanced detection and delay elements reduce the vulnerablity to insider and to forced entry threats. Personnel access is carefully controlled and the three control centers continually interact to assure the proper movement of material.

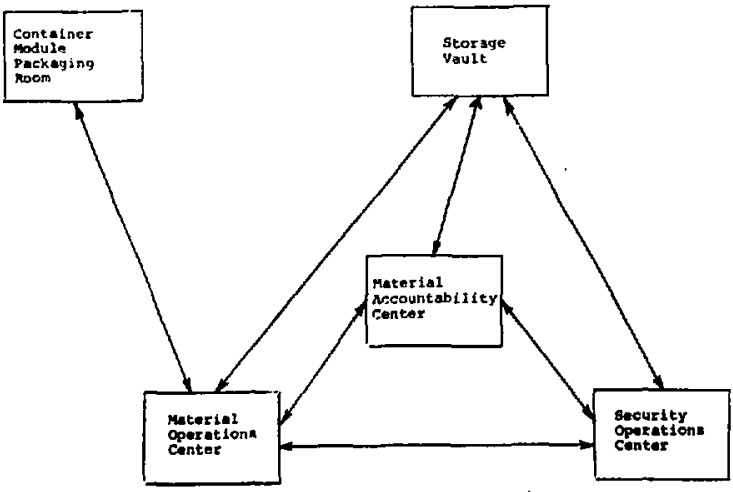

Elgure 1. Plutonlum Protection System Organization 


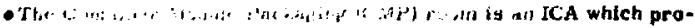

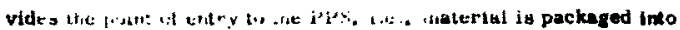

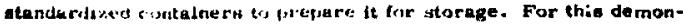

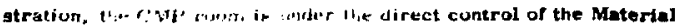

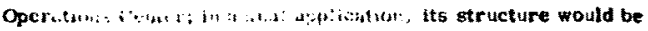
simil $!, \ldots,, \because, \ldots, \ldots, \ldots, \ldots, \ldots, \ldots, \ldots l$ and interaction

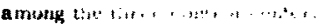

- The Material (jprations ('siter (MCX:) is a control center which monitors and cont rols all operations involving movement of ttems in the syatem.

- The Material Accountabluty Center (MAC) is a control certer which indmatng the arcountabilitv of a'l items in the gystem.

- The siter. monitor and respund" to all alarms in the syatem and controls personnel access to varlous parts of the aystem.

Movement of material between the vault and the CMP room fo accomplitahed in a secure fashion by means of a Secure Transport Module (STM), which is essentially a mintvault on wheels. The STM must be securely docked at a port in the wall of the ICA before material can be loaded or unloaded. The actual transport of matorial is carpfully timed to minimize the time available for tampering or divereton.

The focal point of the PPA to the vault, which includes a personnel entry corridor, ${ }^{2}$ alarm and assegsment components, a protected computer, and a atorage room that contalna Secure Storage Modules (SSM).3 The first three itemi carofully control acceas to the otorage area, while the SSM provides physical barriers and alarma to detect any attempt to gain unauthorized accese to the wored items once entry to the otornge area is achieved.

Closed circutt television (CCTV) is used throughout the PPS to provide a rapid alarmassensment capability and to enable remote ldantificution of parsonnel.

The primary function of the asgesement portion of the CCTV aystem is to produce a pleture of the area where an alurm occura and to diaplay the scene on a video montor in the soc operator' console. The operator can thon determine quickly if unauthorized entry hei been made. The CCTV aystem cen also play a survellance role by monitoring authorlzed persorwal movemeata during normal trenasctions. 
The Identification function is handled by TV cameras which display the image of a person requeating access to the sensitive areas of the PPS. This image is compared by the soc console operator to a televised file photograph of the individual requeating acess.

\section{Suninary}

In the PPS development project at Hanford, closed circuit televlsion cameras are located in areas of critical importance. They assess Int rusion alarms. Identify persons requesting area access, and monitor routine authorized trangactions and maintenance. These critical areas Include the vault, both sides of the vault identufication booth, and the entry corridor on the first noor of Bullaing 234-5Z. On the aecond noor, an entry door and hallway and the ID booth areas are viewed by the aseesament TV camerus. In adolion, each 10 booth contakns TV camera that views the face of a person requesting access for comparison with a TV-viewed slle

photograph of the authorized person. Another camera in the vault ID booth is positloned averhead to vlew the entire booth and determine the activity therein. Figure 2 la a layout of camera positions.

\section{anin $234 \cdot 5$}

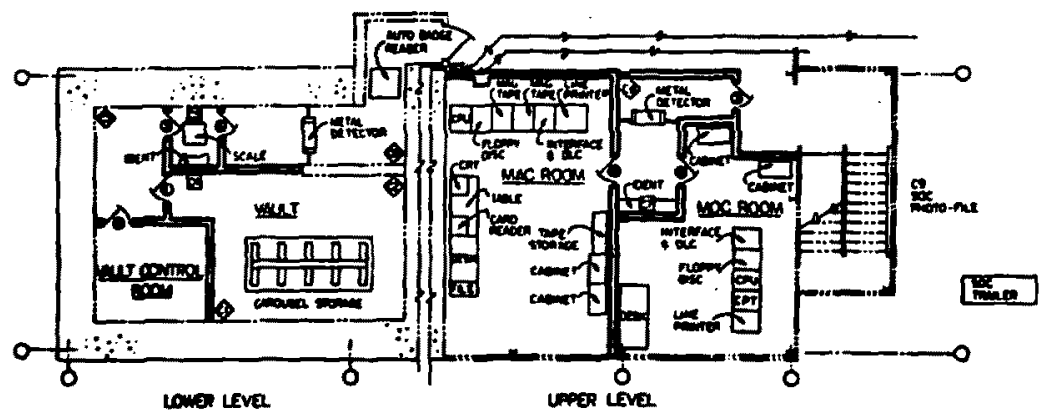

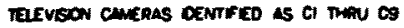

Figure 2. Phytelel Layout of Cameres (Dwe T59821)

All video unen exd the buildins and terminate in the SOC video equipment ruck. The video Ines pae through video clampere and are routed to the Inpute of the Remote VIdeo Switcher (RVS).

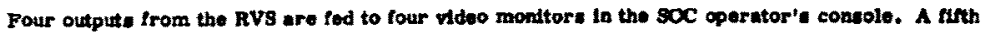
video output is und withth the videp equipment rack to monitor the camore video inputs for proper adjutmonse, when required. Figure 3 is a block diegrim of the rideo ayntem. 


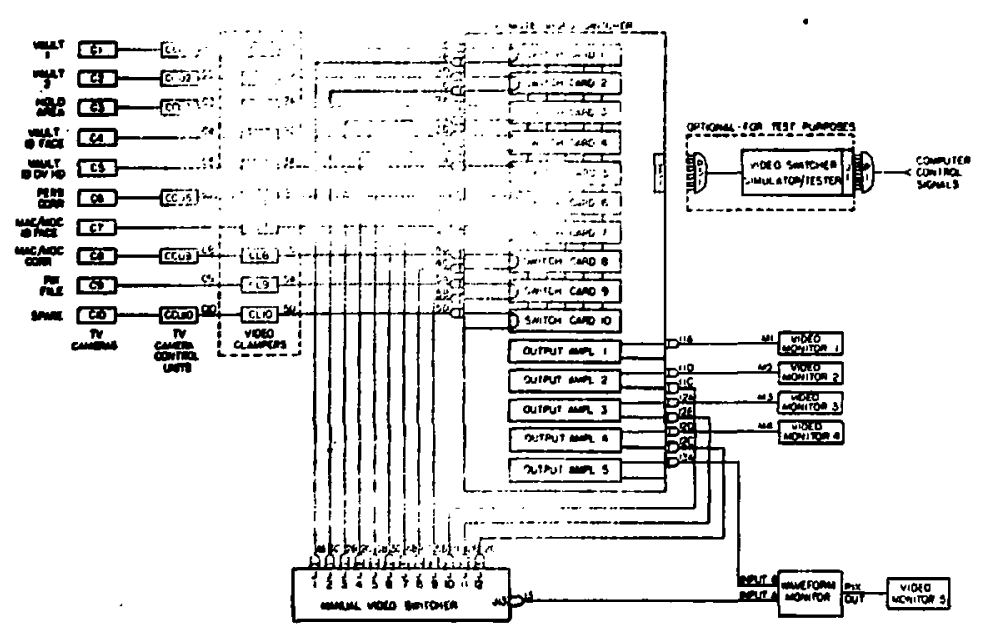

Figure 3. Block Diagram of TV System (Dwg WD-T58622)

Component Iescription

\section{Assessment Cameras}

All assessment cameras are Cohu Electronics, Inc, Model $2820 B$ with $\mathrm{f} / 1.8,6-\mathrm{mm}$ focal length lenses which produce a horizontal field of view of approximately $\theta 0$ degrees. The image tube is a standard (antimony trisulphide) Type 8541 A vidicon. The camera and lens are enclosed in an environmental houging, sealed from the outside at mosphere and pressurized to about 20 to $35 \mathrm{kPa}$ ( $\mathrm{k}$ to $5 \mathrm{psi}$ ), relative to the almasphere, with a nonfammable gas. Internal desiccant packs maintain a low-relatlve humldity.

The cameras were modified to include Curtis Model 520CP3 microcoulometer-type elapgedtime meters to indicate the total uperating time of the cameras. The meter is visible through the glasg feceplate of the camere. The vertical bync lo locked to the ac power frequency $(60 \mathrm{~Hz})$ which reduces the effects of minor 60-Hz line noise induced into the video lines and provides smoother video awitching from camer (cemera eneltivity), electrical focus, and blunking level can be adjusted remotely In the SOC video equipment rack. 
The environmenta1!: \&!ik ssed catriera was chosen to protect camera circuitry from moderate levels of radiation and provide relatively easy alpha decontamination of the exterior. The housing also keeps foreign matter from entering the camera circuitry and preventa an internal camera malfunction Irom creating a fire hazard to the surrounding area. A complete operation and maintenance manual is published by Cohu: hanual Code No. 6X-647, revised October 10, 1976.

\section{Identification Cameras}

The ID booth at the vault comtains two television cameras, the ID booth at the MAC/MUC has only the face-viewing camera, and the photograph file has the fourth identification camera. All ID cameras are Telemation Model TMC-1100SD, with silicon diode array image tubes. Although they have somewhat reduced resolution when compared to the standard vidicon, the silicon array tubes have greater sensitivity and will not suffer permanent Image burn-in when viewing high-light levels continuously. They do, however, produce extended highlight areas (bloaming) if exposed to moderate- to high-light sources in the viewed scene. These cameras are not environmentally gealed, they cannot be remotely controlled, and the vertical aync is not linelocked as are the assessment cameras. A single JRG-59/U coaxlal cable brings the video output from each of the ID cameras to the SUC.

\section{Cables}

The cables connecting the asaessment cameras to the camera control unitg are supplled by Cohis and are designated as CA-66 Cable Assemblies complete with factary-ingtalled connectors. The cable consists of two coaxial (coax) cableg, one seven-conductor ghielded cable, three twisted pairs and elght individual conductors. These conductors are covered with an overall braided shield and jacketed with extruded polyurethane. The cable supplies ac power to the camera, the return video signal, and several remote control functions deacribed previously. The cable Iengths vary from 64 to 79 metres (210 to 260 feet) from the various vault-area cameras to the SOC. A wiring and function diagram of the cable agsembly appears in the Cohu Camera Manual.

Cables for the Identification cameras are RG-59/U coaxial cables (75-ohm Impedance).

\section{Camera Control Units}

The camera control units (Cohu Model 2380-100) are uged on the assessmem cameras only and provide for the remote control of the ac power, manual or automatic control of the imagetube target voltage (gensitivity), electrical focus, and blanking level. These untte, located in the SOC, allow necessary periodic adjustments to the camera as its oporating time increases and It components age without the need for remoral and disassemibly. This capability is most significant when many video gources must have equivalent amplitudes and blaniding levels to permit switching from one camera to another without hevilg to readjust the montor of each camera for contrast (video amplitude) and brightnegs (blaniding lovel). If a malfunction occura, the ac power to the camera can be turned off at the camera control unit to prevent further possible camera 


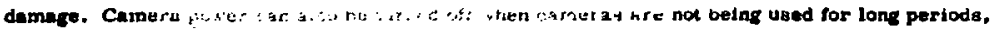

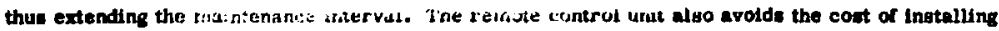
power outlete at euch camera lccation.

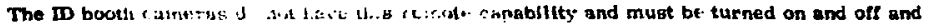
readjusted in place.

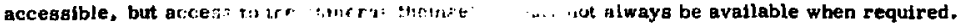

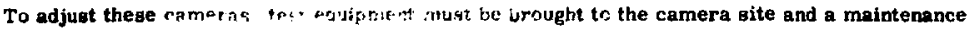
computer transaction mist te intiated t:s allow !n rasnisl to gain access to the vault and MAC/ MOC ID areag.

\section{Video Clampers}

The video cables from the ID carnaras ard the remote control units of the assegsment cameres enter the jupucy if the visteo clamperg. Thit purpose of the clamper is to eliminate the

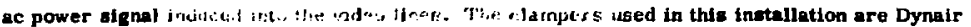
Model CL-1050B which, ref dirt a vicieo aignal inf ut of at least 0.5 volt, penk to peak, to cperate. If tine losieg were grgaler ur longer calle lengths wers used, a video equalizer would be required to bring the video level to the proper amplitude lor input to the clamper. Two clampers are contained in each Dynair Module Frame Model FR-1000A and are auplied power by Dynalr Model PS-1006A Supply also contained in the FR-1000A Module Frame. A gain control on the front of the clamper module allows some limited adjustment to the video output amplitude. The clamper output video signal is avsliable at two 75-ohm, source-terminated, unbalanced-rf connectors of either the whe or BNC " type. A single vdeo output connects the clamper to the RVS by RG-59/J coaxial eable.

\section{Remote Video Switcher}

The remote video bwitcher is a Cohu Model 9100 Video Switcher with a maximum capacity of 20 inputs and 5 outputs which produce a maximum of 100 video ewitching combinations or crosspoints. The eclection of a crosepolnt, that is a partlcular input selected to appear on a particular output, is controlled by applying poaltive-one logic adenal ( +5 volte) to the proper Input control gifnal connector pin. The video output algnal then eppears at one of Ive output amplifiers. Each tnput video signal is applted to a gingle dealgnated owitch card which has five output lines. Only one Input can be selected to appenr at any aingle output amplifier card. Eech output amplifier is deaignated for a particular monitor.

Bavonat type si ineking cistrine developed by Nell and Concelman. 
Four output amplifier's provlde the video signals to the four video monitors in the SOC console. Three of these manitars display video stgnals which the SOC computer has aelected and cannot be used manually. The fourth monitor is used to display the video from a camera manually selected by the SOC console uperator. The fifth output of the remote videa switcher is routed to the waveform monitor (risililoscopi) and a video monitor in the video equipment rack to use in the

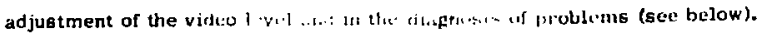

\section{Video Monitors}

The four video montors in the SOC console and the single one in the video equipment rack are Conrac Model SNA9 gerieg, with a $223-\mathrm{mm}$ (9-in. $/$ diagonal picture tube. In the SOC console. the monitors are mounted in pairs, each pair mounted in a side-by-side configuration in is single 483- mm (18-in.) rack (rame, occupying $222 \mathrm{~mm}(8.75 \mathrm{ln}$.) of vertical rack space. The video monitor in the video equipment rack is mounted in a side-by-Bide configuration with the waveform monitor in a common rack frame, requiring $222 \mathrm{~mm}$ of vertical rack apace.

\section{Diagnostic Equipment}

When many video sources must be displayed on a single monitor, the characteriatica of each source must be almost identical to those of all the other sources to preclude the necessity of adjuating the monitor brightness and contrast for each of the video sources. The only way to accomplish this is to observe the individunl video sources and make remote camera adjustments accordingly. The waveform monitor is a special type of oscllloscope used to analyze the video Bignal; the standard oscillosccpe is extremely dificuit to synchronize from the video signal since all the sync pulses are of a constant amplitude but vary in frequency and duration. The waveform monitor uged in this inatallation is a Tektronlx Modal $1480 \mathrm{C}$ whose output feeds a Conrac Model SNA9 vcico monltor in the sa:ne rack frame. With this combination, it is possible to set up the cameras for accurate dynamtc range and pesk-to-peak video amplitude. A video monttor alone will not provide the necessary information for accurate adjustments in multiple source systems.

A Dynair Model VS-12I,-A passive video awitcher gelects the input video to the waveform monitor. The video inputs are obtained (rom the bridging (hich impedance) inputs of the remote video gwitcher by RG-59/U conx ceble. All of the video lines are terminated in 75 ohms in the passive video switcher except the manunlly-aelected vidoo source which is terminated at the waveform monitor input.

A video switcher simulator/tester is a device inverted between the control inputa trom the computer and the RVS. A light emitting diode (LED) is connected to each video crosepoint in the RVS to indicate which crosepointe are activated. During Inotallation and checkout, the almulator / teeter can aubstitute for the computer and manually-controlled Inputs to verify operation of the owichins and diepley equipment. When normal cperations are eatabliahed the simulator/teater 
can be uned to isolate any control or awitching problems which may develop, or can be uned when control siganels from the SOC computer are not available, whatever the reaton.

\author{
References
}

1. R. S. Howard, A Secure Transport Module for the Plutonium Protection System, SAND78-0688, Sandla Laboratories, Albuquerque, New Mexi co, June 1978.

2. W, K. Ream, Personnel Entry Corridora for the Plutonium Protection System, SAND78-1153, Sandila Laboratorieg. Albuquerque, New Mexico, June 1978.

3. R. S. Howard, A Secure Storare Module for the Plutonium Protection System, SAND78-0686, Sandia Laboratories, Albiquerque, Now Maxdco, June 1878.

4. H. G. Swler, Operations Manial for \& Vldeo Comparntor Syatom, SM VDCOMP-1, Sandia Laboratories, Albuquerque, New Moxico, Alegust 1978 , 
DISTRIBUTION:

US Department of Energy (5)

Waghington, DC 20545

Attn: Burt Newmark, MS A-21016 (2)

Safeguards and Security

L. Beckjord, MS F-305

Nuclear Power Pevelotent bivision

G. Oertel, MS 15-107

Waste Managenent Division

C. B. Pleat, 115 15-107

Advanced Systems \& Materials Prod, Div.

US Department of Energy

Albuquerque Operations Orfice

P.O. Box 5400

Albuquerque, NaI 87115

Attn: J. P. Crane

Division of Safeguards \& Security

Nuclear Regulatory Commasion

Washington, DC 20545

Attn: F. J. Arsenault Divtalon of Safeguards, Fuel Cycle and Environmental Reaearch

Los Alamos Scientific Laboratory

P. O, Box 1633

Los Alamog, NM 87545

Attn: W. H. Chambers, Q-DO, MS $\mathbf{5 5 0}$

Argonne National Laboritory

9700 South Cags Ave

Argonne, IL 90439

Atin: P. Persiani

US Department of Energy (2)

Richland Operations Orilce

P. O. Box 550

Richland, WA 99352

Atth: K. L. Jackson

Safeguards \& Security

G. J. Mishko

Nuclear Procesging Branch

Atomics International Division (2)

Rockwell Hanford Operations

P. O. Box 800

Richland, WA 99352

Attn: R. E. Heineman

R. J. Staudacher
1730

1750

1754

1757

1758

1760

1761

1762

1763

1765

1765

1765

1765

4400

4720

8266

3141

3151

DOE/TIC (25)

G. A. Fonler

W. C. Myre

V. E. Blake, Jr.

C. H. Mauney

J. E. Stiegler

J. F. Ney

V. K. Smith

C. E. Olson

J. Jacobs

T. A. Sellers

II. E. Hansen

Attn: E. A. Bernard (5)

1. G. Waddoups

D. S. Miyoshi (2)

F. Aaymond (2)

L. Minnear (2)

D. A. Greenwoll

A. W. Snyder

V. L. Dugan

E. A, Aas

T. Wertier (5)

W. L. Garner (3) For DOE/TIC \{Unlimited Release)

(1. P. Campbel1, 3172-3) 